\title{
The Electronic Booklet on Teaching-Learning Process: Teacher and parents vision of students in primary and secondary education
}

\author{
António Abreu, ISCAP/IPP, Porto, Portugal: aabreu@iscap.ipp.pt \\ Álvaro Rocha, University of Coimbra, Coimbra, Portugal: amrocha@dei.uc.pt \\ João V. Carvalho, ISCAP/IPP, Porto, Portugal: cajvidal@iscap.ipp.pt \\ Manuel Pérez Cota, University of Vigo, Vigo, Spain: mpcota@uvigo.es
}

\begin{abstract}
This article presents the first phase of a research project whose goal is to introduce a new form of collaboration and communication between the school and the family through a Electronic Booklet (EB). The EB appears to meet the growing collaboration needs between school and family and promote the teaching-learning process and educational success, supported by information and communication technologies. We sought to identify through a questionnaire the perceptions of teachers and guardians regarding the adoption of EB. Both groups stressed the importance of communication between school and family and expressed interest in the EB as a communication tool.
\end{abstract}

Keywords-School: Family; Collaboration school/family; Communication; Electronic Booklet.

\section{Introduction}

As in the past, today communication is a key factor in human relationships. They ways to communicate have undergone changes but their essence has remained the same. The human being, beyond the personal direct relations developed communicational processes through long distance contacts.

We aimed, essentially to contribute to what refers to the communication between school and the family. This is a widely discussed matter on research literature, but as Dusi (2012) and Kryger \& Ravn (2009), points it, although this understanding, the relation between parents and teachers, in Europe, from Spain to Sweden and Denmark, from Ireland to Greece, and from Italy to the Czech Republic, and we, in Portugal, presents itself as an unsolved question. Dusi (2012) also refers that the investigation that has been made and parents and teachers statements stress that a good cooperation between school and family is useful in terms of children's education and learning. In this same sense, Lawson (2003) quoting Epstein (2001), Carvalho (2000) and Henderson \& Berla (1994) refers that the parents' appropriate involvement in school matters, not only contributes for a better academic performance from theirs children, it promotes other benefits, like a good behavior of the students and improves teacher's efficiency. On the other hand Epstein (2010) affirms that there are many reasons to develop the partnership between school and family, being, however, the main helping the young ones to achieve school success and in their future life. On Mitchell's (2008) perspective in the educational cycles on contemporary America the parental involvement on their children's educational experiences is understood, not only as a complement to the job of educators, but also as an essential and critical support to the psychological and emotional development of the children.

According to Epstein (2010), it becomes necessary that teachers are capable of seeing the pupils as children, so that they can see the family as a partner in the education of the children. In the study we developed, and which focus on the reality of the Portuguese schools, we aim at showing, not only the importance of the parental involvement, since that side has already been profusely studied and demonstrated in literature, but to enhance the importance of 
proposing new means of education between school and the family through the development of Electronic Booklet (EB).

The technological revolution has brought many changes observed in several levels of society, like cultural or in education (Abrantes, 2009; Lévy, 2003; Marques, 1998; Mattelart, 2003) and in the ways of communication, directing, thus a new look into the information society (Groves et al., 2011; Guimarães \& Sarsfield Cabral, 2010; Salvador \& Rocha, 2014; Abreu et al., 2015), where the communication overtakes the barriers of space and time, creating a virtual world, influencing the individuals' way of thinking and acting.

A changing world, supported in a society of information imposes a new approach to education (Skilbeck, 1998). Therefore comes the necessity of the school to use new technological resources, not only creating the necessary conditions to the development of an education to an with the technologies, but also developing, resorting to technologies, new ways of communication between school and family (Berto \& Nakano, 2014, 2000; Boonen, 2000; McLean, 2009; Sarmento, 2005; Sarmento \& Marques, 2002; Silva, 2002; Villas-Boas, 2000). It is in this perspective that we speak of the Electronic Booklet (EB), developed in our research work, as a response to the technological evolution and the need of improving the process of cooperation between school and family, as a way of guaranteeing an improvement in the learning process and educational success (Lima \& Sá, 2002; Lourenço, 2008; Marques, 1992, 1998; Montadon \& Perrenoud, 2001; Villas-Boas, 2001; Castells, 1999, 2002, 2003).

Schools therefore need to wage on the Information and Communication Technologies (ICT) students, parents and schools need to be online, since they are the main intervenients in the learning and teaching process (Alho \& Nunes, 2009; Grant, 2009; Abreu et al. 2015). Acknowledging that parents become, sometimes, strange elements to the school life and that it is relevant to potentiate the participation through information which is made available to them, we aim at developing a study which has as a starting point the following aims (Silva et al. 2013; Bhering, 1999):

- Evaluate the relevance of the EB in the school family relationship;

- Understanding the role of EB in the school family relationship.

Based on the goals outlined for his study, three questions were sketched to be investigated:

- Is the communication between school and family fundamental in the learning teaching process?

- Is the traditional booklet (TB) a fundamental instrument in the communication between school and family?

- Does the EB potentiate and improve the communication between school and family?

The study involved several schools in Portugal. The development process of the investigation was developed in three stages. On the first stage of the investigation process a study of the practicability of the adoption of the EB in the relation school family, through the perceptions of Parents and Teachers. So a questionnaire was made available to the adhering schools. It was a school board task to select the sample of Parents and Teachers; the second stage consisted in the development and implementation of the EB prototype; and on the third stage of the study we made an evaluation of impact of the EB.

This article is on the first stage of the study and was based on the following set of objectives:

- To characterize the perceptions of both Parents and Teachers about the school family relationship; 
- To characterize the perceptions of both Parents and Teachers about the educational role of traditional booklet (TB);

- To foresee the advantages and disadvantages of using EB and TB;

- To characterize the perceptions of both Parents and Teachers about the possible educational advantages of the adoption of an EB.

\section{The communicational process between school and family}

In schools the ICT are used, however many times their full potentialities are not exploited (Castells, 1999, 2001). The schools can only win from a good use of the ICT, not only from a pedagogical point of view, as well as the school management point of view, and even, from the point of view of the communication between school and families.

What happens is that there is a deep hole between the understanding of the need of the effective use and implementation of the information technology at the level of communication should be established between the School and the Family (Beaudichon, 2001). These contacts must not be restrained to the mere occasional and fortuity, of reduced influence on the educational process, as has been the most frequent scenario on most school (Anastasi, 1990; Despacho $\mathrm{N}^{\circ}$ 38/SERE/88, 1988). So, it is important to find ways to facilitate the communication (Pedro \& Matos, 2010; Gepe, 2010).

Nowadays, to make certain communications, the Teachers and Class Directors resort to the TB. The underlying aim to the creation of TB is related with the improvement of the collaboration process between school, student and its family. Under this inclusive perspective, and in the realm of school autonomy, the TB is an instrument that allows:

- See the name of the Teachers, the Class Director and Class Delegate, the school calendar and the school activities, as well as the services the school has available for the student and the guardian;

- Useful information's reporting to the student, allowing the Class Director and the school to perform in a more concrete and assertive way on serious situations with the student, as for example in case of illnesses or serious indiscipline;

- A better knowledge of the school about the student, specifically, on what concerns extracurricular activities;

- To communicate with the Teachers and the Class Director in multiple situations, like:

o Alert the Teachers for situations related to the student's health;

o Answer to demands made by the class teachers;

o Acknowledge activities that took place in school or made by the school;

o Acknowledge of noteworthy behaviors by the student or, on the other hand, not so noteworthy behaviors;

o Justify the student's absences.

The generalization of the use of TB (Batista, 2005) was widely valorized by the educational community on the early years of its implementation (despacho, $\mathrm{N}^{\circ} 38 / \mathrm{SERE} / 88,1988$ ). This is is not, however the most direct means to contact the family, since it requires to resort to the student and, on the other hand, it limits the communicational content (Montadon \& Perrenoud, 2001). What Parents and Teachers need to say is limited to a few lines in a TB.

As time goes by we have verified that Teachers and Parents still use the TB, but do it, essentially, in the following situations: 
- On school level the uninterested is displayed on filling of the TB. The practices of fully filling the TB seem to have been abandoned;

- On family level the reduction of TB to a mere instrument to justify absences and sharing of student's clinical situations.

The contacts between school and family must not be limited to mere occasional and fortuitous relations, of reduced influence on the educational process, as has been the most common case with many schools (Batista, 2005; Lourenço, 2008). It is important to find ways to facilitate the communication (Silva et al., 2013; Abreu et al., 2015; McLean, 2009)

It was based on this reality that arouse the necessity of the evolution of the TB, making it a more dynamic and attractive instrument to the family and to the school. As is referred by (Batista, 2005) we have to establish cooperative networks between the intervening partners, which can be achieved resorting to the EB. Among the countless applications of the ICT, which go from the use of generic software's like the Text Processor or the Spreadsheet and specific software's to learn competences demanded by several subjects, to the exploitation of the online tools, school has to try to fully use them in favour of the communication with the educational partners, like the Parents.

If school is capable of communicating, actively an efficiently, it is possible to establish a relation of trust and cooperation among all the partners involved. Before this reality, school need to take the technological innovations to the school context and use new Web services. Therefore, school need to bet on Information and Communication Systems. Students, parents and schools need to be on-line, since they intervene in learning/teaching process (Grant, 2009).

\section{Reasearch Methodology}

To this part of the study, it seemed adequate to resort to a quantitative investigation methodology (Gil, 1999; Pardal \& Correia, 1995) since this allows to "(...) gather the facts and study the relation between them" (Bell, 2002), and, also allows to "(...) compare the averages relatively to the degree of variation of the results, to determine the differences that were achieved (Tuckman, 2005).

The quantitative techniques allow the gathering of the data through several instruments, like tests and measurings; or allow the gathering of information on a checklist through one questionnaire (Ghiglione \& Matalon, 2001; Hill \& Hill, 2002, 2005; Quivy \& Campenhoudt, 2005; Creswell, 2003).

In this our research work, we resorted to the method of research of inquiry by questionnaire. We resorted to the method of research of inquiry by questionnaire to allow us to: obtaining data on the TB contribution to an effective and speedy communication between school and family; about how they can improve communication and accelerate the processes of collaboration between school and family and whether the EB can be a platform to enhance the synchronous communication between the school and family. We chose the inquiry by questionnaire because we understand it is a viable and desirable method in the school realm, and it also generates precise and reliable measures which allow for statistical analysis (Groves et al., 2004). Since we could not find an appropriate questionnaire to the purpose of the study we developed and applied our own questionnaire.

A research of the inquiry by questionnaire type, which by rule uses as gathering data instrument a questionnaire (Berto \& Nakano, 2014, 2000), involves the gathering of data in a large sample about the problem which is being studied in order to, afterwards, through analysis, to reach the conclusions about the gathered data (Gil, 2010). 
To create the questionnaire we carefully studied the theme in order to be able to write a set of questions. We chose to select the questions we thought were more important, regarding the goal of the investigation (Canhota, 2008; Mackey \& Gass, 2005).

The questionnaire is made of two parts: the first one relates to the characterization of the sample and the second one corresponds to the questionnaire.

On the first one, corresponding to the characterization of the sample, were included some items which allowed to understand if the sample presented correct knowledge about the problem being studied. On what regarded the parents, the following items were included: student's school and school year, academic qualifications, age, gender, role they play on the student's school. On what regards the teachers we chose the following items: school where they teach, subject, academic qualifications, age, gender, year they teach, work time, their function in the school they work.

Part B of the questionnaire refers to the "Student booklet" and part C is related to the inclusion of items in an EB. Part B of the questionnaire related to the "Student's booklet" is complete with 15 statements and two open answer questions, in order to allow the participants in the study to indicate the advantages and disadvantages on the use of the EB; and part $\mathrm{C}$ of the questionnaire which is relates to the "Inclusion of items in an EB" was complete with two questions, one of them was a closed type of question, but allowing the participants, if they answered negatively to say the items from the TB that should not be in the EB; and the other question had five statements. We used a Likert ordinal scale with five answer options (from " 1 " To "5") from "completely disagree" to "completely agree" because we understand it is adequate to measure the level of agreement or disagreement to the statements placed in the questionnaire. In the analysis and presentation of the results we chose to join the "completely disagree", with the "partially disagree” and the "completely agree” with the "partially agree”, I order to make it the questionnaire shorter and increase the dynamic of the answers.

It is our purpose to evaluate the need of evolution of the TB, making it a more dynamic and more attractive instrument to the family and to the school, which can be achieved resorting to the EB.

Based, either on the reality of the schools on what refers to the communication with the student's parents, either on the goals outlined by this research and as a way to develop a study the following assumptions were formulated:

A1: The educational community values the communication school-family.

A2: The TB is a fundamental instrument in the communication school-family.

A3: The EB improves the communication between the school and the family.

A pre-test was made with a small scale sample, with the goal of clarifying and validating the questionnaires (Fortin, 2009). This sample had thirty people connected to education (Teachers and Parents) that accepted to participate. The pre-test was delivered and collected personally. After the recollection and analysis we made an informal reunion who participated on the pre-test. The participants were unanimous about the objectivity of the questionnaires, presenting no difficulties on its completion. There was just one doubt raised about the parents questionnaire, on the question about the academic qualifications. From the participant parents two had doubts if they should answer with their own academic qualifications or their children's, the appropriate answer was immediately clarified.

Two inquiries by questionnaire were made between the months of November 2013 and January 2014. The questionnaires were placed on paper and on-line, regarding the availability to answer of the participants in the study and according to the option of the school headmaster. Personal contacts were made, by email and telephone with several schools, to explain the goal 
of the research and ask for their cooperation. It was the headmaster's task to explain the teachers, the class directors and the people from parents associations and parents the goal of the research.

The data collected from the questionnaires was treated using the software SPSS, version 20 (Marôco, 2011). In the analysis that was made we paid attention to the logical thinking of statistical concepts (Anastasi, 1985).

Beyond the mere descriptive analysis of the data, we made a correlational analysis, by crossing some of the variables that were in the questionnaire to find the answer three hypotheses formulated by the research (Pereira, 2006). We used also absolute dispersion measures (pattern deviation) and relative (variation coefficient), useful to describe the variation observed in the values of a conjunct and inform about their homogeneity. Being that the smaller are, $(<1)$ to the pattern deviation and ( $<=20 \%)$ to variation coefficient, the smaller the dispersion and therefore are more homogenous responses.

\subsection{Characteization of the Sample}

The sample was made from the universe of parents and teachers from 20 state schools (Table 1) and 15 private/cooperative schools (Table 2).

\begin{tabular}{|c|c|c|c|}
\hline Public schools grouping & $\begin{array}{c}\text { Schools } \\
\end{array}$ & District & County \\
\hline $\begin{array}{l}\text { Alcaides de Faria Schools } \\
\text { Grouping }\end{array}$ & Alcaides de Faria Secondary School & Braga & Barcelos \\
\hline $\begin{array}{l}\text { Camilo Castelo Branco } \\
\text { Schools Grouping }\end{array}$ & $\begin{array}{c}\text { Luís de Camões School Centre; EB 2,3 Júlio } \\
\text { Brandão; Camilo Castelo Branco Secondary } \\
\text { School }\end{array}$ & Braga & V. N. Famalicão \\
\hline $\begin{array}{l}\text { Carolina Beatriz Ângelo } \\
\text { Schools Grouping }\end{array}$ & Carolina Beatriz Ângelo Basic School & Guarda & Guarda \\
\hline Amares Schools Grouping & $\begin{array}{c}\text { EB 2,3 de Amares; Amares Secondary } \\
\text { School }\end{array}$ & Braga & Amares \\
\hline Anadia Schools Grouping & Anadia 2, 3 Basic School & Aveiro & Anadia \\
\hline Lousada Schools Grouping & $\begin{array}{l}\text { EB 2,3 de Lousada; Lousada Secondary } \\
\text { School }\end{array}$ & Porto & Lousada \\
\hline $\begin{array}{l}\text { Montemor-o-Novo Schools } \\
\text { Grouping }\end{array}$ & $\begin{array}{l}\text { Montemor-Novo Secondary School; EB 2,3 } \\
\text { São João de Deus }\end{array}$ & Évora & $\begin{array}{l}\text { Montemor-o- } \\
\text { Novo }\end{array}$ \\
\hline $\begin{array}{l}\text { Montemor-o-Velho Schools } \\
\text { Grouping }\end{array}$ & $\begin{array}{c}\text { EB 2,3 de Arazede; EB 2,3 Dr. José dos } \\
\text { Santos Bessa }\end{array}$ & Coimbra & $\begin{array}{l}\text { Montemor-o- } \\
\text { Velho }\end{array}$ \\
\hline Sátão Schools Grouping & Frei Rosa Viterbo Secondary School & Viseu & Sátão \\
\hline $\begin{array}{l}\text { Eugénio de Castro Schools } \\
\text { Grouping }\end{array}$ & Solum Basic School & Coimbra & Coimbra \\
\hline
\end{tabular}




\begin{tabular}{|c|c|c|c|}
\hline $\begin{array}{l}\text { Francisco de Holanda Schools } \\
\text { Grouping }\end{array}$ & $\begin{array}{l}\text { EB } 1 \text { Santa Luzia; EB 2,3 Egas Moniz; } \\
\text { Francisco de Holanda Secondary School }\end{array}$ & Braga & Guimarães \\
\hline $\begin{array}{c}\text { Inês de Castro Schools } \\
\text { Grouping }\end{array}$ & Inês de Castro Secondary School & Porto & V. N. Gaia \\
\hline $\begin{array}{c}\text { Luís de Camões Schools } \\
\text { Grouping }\end{array}$ & EB 2,3 Luís de Camões & Lisboa & Lisboa \\
\hline $\begin{array}{l}\text { Marquês Marialva Schools } \\
\text { Grouping }\end{array}$ & EB 2,3 Marquês de Marialva & Coimbra & Cantanhede \\
\hline $\begin{array}{l}\text { Martim de Freitas Schools } \\
\text { Grouping }\end{array}$ & EB1Conchada & Coimbra & Coimbra \\
\hline Matosinhos Schools Grouping & Augusto Gomes Secondary School & Porto & Matosinhos \\
\hline $\begin{array}{l}\text { Padre Benjamim Salgado } \\
\text { Schools Grouping }\end{array}$ & Padre Benjamim Salgado Secondary School & Braga & V. N. Famalicão \\
\hline $\begin{array}{l}\text { Professor Abel Salazar } \\
\text { Schools Grouping }\end{array}$ & EB 2,3 Abel Salazar & Guimarães & Guimarães \\
\hline $\begin{array}{l}\text { Santa Iria de Azóia Schools } \\
\text { Grouping }\end{array}$ & EB 2,3 Santa Iria de Azóia & Lisboa & Loures \\
\hline $\begin{array}{c}\text { Senhora da Hora Schools } \\
\text { Grouping }\end{array}$ & EB/JI Quinta de S. Gens & Porto & Matosinhos \\
\hline
\end{tabular}

Table 1: Public schools groupings from the sample

\begin{tabular}{|c|c|c|}
\hline Private/Cooperative Schools & District & County \\
\hline Padre Ramos Social Centre & Porto & Lisboa \\
\hline Lisboa Bilingual School & Lisboa & Trofa \\
\hline Trofa School & Porto & Vagos \\
\hline Nossa Senhora da Apresentação Diocesan School & Aveiro & V. N. Famalicão \\
\hline Machado Ruivo School & Braga & Braga \\
\hline Calouste Gulbenkian Conservatory of Music & Braga & V. N. Famalicão \\
\hline Ensino Riba de Ave Cooperative Didaxis & Braga & V. N. Famalicão \\
\hline Vale S. Cosme Didaxis & Braga & Santo Tirso \\
\hline Ponte School & Porto & Vila Verde \\
\hline Amar Terra Verde - EPATV Professional School & Braga & V. N. Famalicão \\
\hline Delfim Ferreira Day-School & Braga & Porto \\
\hline Ribadouro Day-School & Porto & Porto \\
\hline INED Nevogilde - Porto & Porto & Coimbra \\
\hline Lordemao Institute & Coimbra & Cartaxo \\
\hline
\end{tabular}

Table 2: Private/cooperative schools groupings from the sample

\subsection{Factorial Analysis}

We made and analysis of the data to the questions on the parts $\mathrm{B}$ and $\mathrm{C}$ of the questionnaires of the Parents and Teachers, recurring to the data treatment techniques that agglomerate the initial information, aiming to facilitate its analysis.

According to Pereira (2004), technique used in the factorial analysis, consists of calculating all the correlations among all the variables and isolating the main factor.

To Angelo (1991), the factorial analysis is a statistical technique which allows to identify a reduced number of facts that can be used to represent a set of interconnected variables.

In this project we chose the method of main components, to isolate the original variables that are correlated to each other, constituting the factors.

The method of factorial analysis, analyses a set Booklet of variables with the objective of verifying if it is possible to aggregate a set of answers that are interpreted identically by elements of the sample, determining their positioning in that set of variables (Stevens, 1996). 
The factorial analysis, made either for the Part B, either for the part $\mathrm{C}$ of the Teachers and Parents' questionnaires, allowed to proceed to the transformation of the variables which constitute a scale in a smaller number of factors: the main components.

On the B part of Teachers and Parents' questionnaires, relating to the "Student Booklet", we extracted the factors from the 15 variables (Table 3).

\begin{tabular}{|c|c|}
\hline \multicolumn{2}{|r|}{ Part B of the Teachers and Guardians questionnaires - "Student Record". } \\
\hline Number & Item \\
\hline 1 & The relationship between the family and the school is fundamental for the teaching-learning process. \\
\hline 2 & $\begin{array}{l}\text { The relationship between the school and the family is not always easy and stands out as a complex } \\
\text { relationship. }\end{array}$ \\
\hline 3 & Whenever the parents are involved the development of the students is potentially improved. \\
\hline 4 & $\begin{array}{l}\text { The participation of parents in the school benefits the Teachers and contributes to a more constructive } \\
\text { work on their part. }\end{array}$ \\
\hline 5 & $\begin{array}{l}\text { Parents assume more favourable attitudes towards Teachers when they cooperate constructively with } \\
\text { each other. }\end{array}$ \\
\hline 6 & $\begin{array}{l}\text { Parents can easily head to the school during the receiving hours appointed by Class Directors and in } \\
\text { meeting days. }\end{array}$ \\
\hline 7 & The Traditional Student Record constitutes an important tool in family-school communications. \\
\hline 8 & Teachers regularly use the Traditional Record in their communications with Guardians. \\
\hline 9 & $\begin{array}{l}\text { It is important to find a tool that will allow for the intensification of and an easier communication } \\
\text { between the School and the Guardian. }\end{array}$ \\
\hline 10 & $\begin{array}{l}\text { The adoption of an Electronic Booklet may contribute to an improved communication between the } \\
\text { school and the Guardian. }\end{array}$ \\
\hline 11 & $\begin{array}{l}\text { An Electronic Booklet may constitute an important work tool for Class Directors, Teachers, Parents } \\
\text { and School Principals. }\end{array}$ \\
\hline 12 & $\begin{array}{l}\text { An Electronic Report may constitute a communication resource between every Teacher and } \\
\text { Guardians. }\end{array}$ \\
\hline 13 & An Electronic Booklet may be used by School Principals to contact Teachers. \\
\hline 14 & An Electronic Booklet may be used by School Principals to contact Guardians. \\
\hline 15 & $\begin{array}{l}\text { An Electronic Booklet offers more advantages than the Traditional Booklet where the communication } \\
\text { between the multiple school community actors is concerned. }\end{array}$ \\
\hline
\end{tabular}

Table 3: Part B of the Teachers and Guardians Questionnaires - "Student Booklet".

We started the analysis applying the Kaiser Meyer Olkin (KMO) tests and the Barlett, that allow to conclude about the quality of the factorial analysis of the data of the sample (Bartlett, 1951; Kaiser, 19714).

After analysing the results of the tests, $K M O$ with the result of 0.887 and Bartlett with a significance value inferior to $5 \%$, that is, with the value of $p$ of the significance test inferior to 0.001 practically in all cases (Table 4), it will be possible to execute the factorial analysis to the data of the sample, of the B component of the questionnaires to the Parents and Teachers, properly (Leong \& Austin, 2006)

\begin{tabular}{lcc}
\hline Sample adequacy measurement Kaiser-Meyer-Olkin. & $\mathbf{0 , 8 8 7}$ \\
Sphericity test Bartlett & Chi-square & 9443,083 \\
& Degrees of freedom & 105 \\
& Probative value & $* * 0,000$ \\
\hline
\end{tabular}

Table 4: Results of tests KMO and sphericity Bartlett- ** The value of $p=0.000$ is common in nearly all cases it applies the factor analysis.

After verifying the possibility to execute adequately the factorial analysis and using the main components method, we proceeded to extract the factors from the 15 variables, using the Kaiser criteria (own values bigger than one), fulfilling the criteria that the factors must explain at least $60 \%$ of the total variation observed in the original variables (Kaiser, 1974). Three factors were retained, that explain $66.7 \%$ of the total variation on the 15 original variables (Table 5) (Tabachnik \& Fidell, 2006). 


\begin{tabular}{|c|c|c|c|c|c|c|}
\hline \multirow[b]{2}{*}{ Component } & \multicolumn{3}{|c|}{ Own initial value } & \multicolumn{3}{|c|}{ After rotation } \\
\hline & Total & \% Variance & \% Cumulative & Total & \% Variance & \% Cumulative \\
\hline 1 & 5,222 & 34,814 & 34,814 & 4,772 & 31,810 & 31,810 \\
\hline 2 & 2,335 & 15,564 & 50,378 & 2,356 & 15,707 & 47,518 \\
\hline 3 & 1,348 & 8,986 & 59,365 & 1,578 & 10,519 & 58,037 \\
\hline 4 & 1,098 & 7,319 & 66,684 & 1,297 & 8,647 & 66,684 \\
\hline 5 & ,787 & 5,248 & 71,932 & & & \\
\hline 6 & ,733 & 4,885 & 76,816 & & & \\
\hline 7 & ,632 & 4,211 & 81,027 & & & \\
\hline 8 & ,570 & 3,797 & 84,824 & & & \\
\hline 9 &, 538 & 3,588 & 88,412 & & & \\
\hline 10 & ,472 & 3,143 & 91,555 & & & \\
\hline 11 & ,443 & 2,954 & 94,509 & & & \\
\hline 12 & 268 & 1,786 & 96,295 & & & \\
\hline 13 & ,238 & 1,584 & 97,880 & & & \\
\hline 14 & 180 & 1,198 & 99,077 & & & \\
\hline 15 & ,138 & ,923 & 100,000 & & & \\
\hline
\end{tabular}

Table 5: Extraction method - Principal Component Analysis

Through the Varimax method, it was possible to maximize the value of the coefficients that relate each variable with the retained factors, in order to make it possible for each variable to be associated with just one factor (Costello \& Osborne, 2005): Factor 1 - EB; Factor 2 Influence of the school-family relation on the teaching-learning process; Factor $3-\mathrm{TB}$; Factor 4 - Difficulties on the school-family relation.

Table 6 presents our factorial matrix after the Varimas rotation, where we observe the saturations between each factor and the main components. The saturation of the variables on each factor are always superior to the required minimum of $40 \%$. In bold we enhance the more significant saturations.

The value presented on the table 6 of -0.661 results from the fact that the item is in an inverted scale. Which is verified at school level, day and time for parents' attendance. That attendance schedule coincides with the time the school is open. However, for most parents the schedule that is available coincides with their work schedule. Since it is a negative value, the introduction of the item 6 on the factor 4 is made by inverting the scale.

\begin{tabular}{|c|c|c|c|c|}
\hline \multirow{2}{*}{ Items } & \multicolumn{4}{|c|}{ Factor } \\
\hline & 1 & 2 & 3 & 4 \\
\hline $\begin{array}{l}\text { 1. The relationship between the family and the school is } \\
\text { fundamental for the teaching-learning process. }\end{array}$ & 0.050 & 0.702 & 0.017 & -0.057 \\
\hline $\begin{array}{l}\text { 2. The relationship between the school and the family is } \\
\text { not always easy and stands out as a complex } \\
\text { relationship. }\end{array}$ & 0.065 & 0.067 & 0.092 & 0.830 \\
\hline $\begin{array}{l}\text { 3. Whenever the parents are involved the development } \\
\text { of the students is potentially improved. }\end{array}$ & 0.124 & 0.741 & 0.084 & 0.125 \\
\hline $\begin{array}{l}\text { 4. The participation of parents in the school benefits the } \\
\text { Teachers and contributes to a more constructive work } \\
\text { on their part. }\end{array}$ & 0.166 & 0.724 & 0.104 & -0.023 \\
\hline $\begin{array}{l}\text { 5. Parents assume more favourable attitudes towards } \\
\text { Teachers when they cooperate constructively with each } \\
\text { other. }\end{array}$ & 0.101 & 0.749 & 0.117 & -0.052 \\
\hline $\begin{array}{l}\text { 6. Parents can easily head to the school during the } \\
\text { receiving hours appointed by Class Directors and in } \\
\text { meeting days. }\end{array}$ & -0.095 & 0.155 & 0.295 & -0.661 \\
\hline $\begin{array}{l}\text { 7. The Traditional Student Booklet constitutes an } \\
\text { important tool in family-school communications. }\end{array}$ & 0.024 & 0.220 & 0.808 & -0.074 \\
\hline $\begin{array}{l}\text { 8. Teachers regularly use the Traditional Booklet in } \\
\text { their communications with Guardians. }\end{array}$ & 0.052 & 0.042 & 0.873 & -0.018 \\
\hline $\begin{array}{l}\text { 9. It is important to find a tool that will allow for the } \\
\text { intensification of and an easier communication between } \\
\text { the School and the Guardian. }\end{array}$ & 0.474 & 0.286 & 0.100 & 0.341 \\
\hline $\begin{array}{l}\text { 10. The adoption of an Electronic Booklet may } \\
\text { contribute to an improved communication between the } \\
\text { school and the Guardian. }\end{array}$ & 0.886 & 0.086 & -0.019 & 0.109 \\
\hline $\begin{array}{l}\text { 11. An Electronic Booklet may constitute an important } \\
\text { work tool for Class Directors, Teachers, Parents and } \\
\text { School Principals. }\end{array}$ & 0.899 & 0.137 & -0.011 & 0.074 \\
\hline
\end{tabular}




\begin{tabular}{|l|r|r|r|}
\hline $\begin{array}{l}\text { 12. An Electronic Booklet may constitute a } \\
\text { communication resource between every Teacher and } \\
\text { Guardians. }\end{array}$ & $\mathbf{0 . 9 0 4}$ & 0.118 & -0.021 \\
\hline $\begin{array}{l}\text { 13. An Electronic Booklet may be used by School } \\
\text { Principals to contact Teachers. }\end{array}$ & $\mathbf{0 . 6 9 8}$ & 0.146 & 0.080 \\
\hline $\begin{array}{l}\text { 14. An Electronic Booklet may be used by School } \\
\text { Principals to contact Guardians. }\end{array}$ & $\mathbf{0 . 8 9 6}$ & 0.0147 \\
\hline $\begin{array}{l}\text { 15. An Electronic Booklet offers more advantages than } \\
\text { the Traditional Booklet where the communication } \\
\text { between the multiple school community actors is } \\
\text { concerned. }\end{array}$ & $\mathbf{0 . 8 8 0}$ & 0.038 & 0.045 \\
\hline $\begin{array}{c}\text { Total Explained variance } \\
\text { Totained variance }\end{array}$ & $\begin{array}{l}31.8 \\
66.7\end{array}$ & 0.052 \\
\hline
\end{tabular}

Table 6: Rotation Method: Varimax with Kaiser normalization. Rotation converged in 5 iterations. N = 1302. $\mathrm{KMO}=0.887$.

On the part $\mathrm{C}$ of the questionnaires for the Teachers and the Parents, the Inclusion of Items in an Electronic Booklet, the participants were faced with 7 items (Table 7).

\begin{tabular}{|c|l|}
\hline \multicolumn{2}{|c|}{ Part C of the Teachers and Guardians Questionnaires - "Inclusion of items in an Electronic Booklet” } \\
\hline Number & Item \\
\hline 1 & Absence justifications by the Guardians. \\
\hline 2 & Absence management by the Class Director. \\
\hline 3 & Mid-term evaluation record. \\
\hline 4 & Evaluation criteria and tools for each subject. \\
\hline 5 & Student self-assessment forms. \\
\hline 6 & $\begin{array}{l}\text { Communication management (Messages, SMS and Emails) between Class Directors, Teachers and } \\
\text { Guardians. }\end{array}$ \\
\hline 7 & Videoconference between Class Directors and Guardians. \\
\hline
\end{tabular}

Table 7: Part C of the Teachers and Guardians questionnaires - "Inclusion of Items in an ER"

After applying the Kaiser Meyer Olkin (KMO) tests and subsequent analysis of the results, we verified that, the value of KMO of 0.881 and Bartlett with a significance value inferior to 5\%, with a value of $p$ of the significance test of less than 0.001 in practically all the cases (table 8), it shows us that we can make our factorial analysis, because the results we will achieve can be considered meaningful (Bartlett, 1951; Kaiser, 1974).

\begin{tabular}{lcc}
\hline Sample adequacy measurement Kaiser-Meyer-Olkin. & $\mathbf{0 , 8 8 1}$ \\
Sphericity test Bartlett & Chi-square & 4784,533 \\
& Degrees of freedom & 21 \\
& Probative value & $* * 0,000$ \\
\hline
\end{tabular}

Table 8: Results of tests KMO and sphericity Bartlett- ${ }^{* \star}$ The value of $p=0.000$ is common in nearly all cases it applies the factor analysis.

After verifying that the possibility to make the factorial analysis correctly, and using the method of the main components, we proceeded to the extraction of the factors from the 7 variables, using the Kaiser criteria (own values bigger than one), verifying the criteria that the factors must explain at least $60 \%$ of the total variation observed on the original variables (Kaiser, 1974). Two factors were retained, that explain $72,6 \%$ of the total variation observed on the 7 original variables (Table 9) (Tabachnik \& Fidell, 2006).

\begin{tabular}{|c|c|c|c|c|c|c|}
\hline \multirow[b]{2}{*}{ Component } & \multicolumn{3}{|c|}{ Own initial value } & \multicolumn{3}{|c|}{ After rotation } \\
\hline & Total & \% Variance & Component & Total & \% Variance & Component \\
\hline 1 & 4,197 & 59,952 & 59,952 & 2,835 & 40,502 & 40,502 \\
\hline 2 & 0,882 & 12,605 & 72,557 & 2,244 & 32,055 & 72,557 \\
\hline 3 & 0,578 & 8,252 & 80,809 & & & \\
\hline 4 & 0,424 & 6,056 & 86,865 & & & \\
\hline 5 & 0,379 & 5,415 & 92,280 & & & \\
\hline 6 & 0,293 & 4,184 & 96,464 & & & \\
\hline 7 & 0,247 & 3,536 & 100,000 & & & \\
\hline
\end{tabular}

Table 9: Extraction method - Principal Component Analysis 
Through the varimax method it was possible to take extreme value of the coefficients relating each variable factors and retained, so that each variable might be associated with only one factor (Costello \& Osborne, 2005): Factor 1 - Register and Review of shortages and Factor 2 Self-assessment of students and communication.

Table 10 shows our factor matrix after Varimax rotation where the saturation is observed between each factor and the principal components. The saturation of the variables in each factor is always higher than the required minimum of $40 \%$. The bold highlight is the most important one.

\begin{tabular}{|l|c|c|}
\hline \multicolumn{1}{|c|}{ Items } & \multicolumn{2}{c|}{ Factor } \\
\cline { 2 - 3 } & \multicolumn{1}{c|}{$\mathbf{1}$} & $\mathbf{2}$ \\
\hline 1. Absence justifications by the Guardians. & $\mathbf{0 . 8 6 1}$ & 0.141 \\
\hline 2. Absence management by the Class Director. & $\mathbf{0 . 8 6 8}$ & 0.248 \\
\hline 3. Mid-term evaluation record. & $\mathbf{0 . 7 6 7}$ & $\mathbf{0 . 4 0 5}$ \\
\hline 4. Evaluation criteria and tools for each subject. & $\mathbf{0 . 5 8 8}$ & $\mathbf{0 . 5 7 1}$ \\
\hline 5. Student self-assessment forms. & $\mathbf{0 . 4 3 9}$ & $\mathbf{0 . 6 6 7}$ \\
\hline $\begin{array}{l}\text { 6. Communication management (Messages, SMS and Emails) between Class Directors, } \\
\text { Teachers and Guardians. }\end{array}$ & $\mathbf{0 . 4 5 8}$ & $\mathbf{0 . 6 6 8}$ \\
\hline 7. Videoconference between Class Directors and Guardians. & 0.054 & $\mathbf{0 . 8 8 4}$ \\
\hline \multicolumn{1}{|c|}{ Total explained variance } & 40.5 & 32.1 \\
\hline
\end{tabular}

Table 10: Rotation Method - Varimax with Kaiser normalization. Rotation converged in 5 iterations. $\mathrm{N}=1302$. $\mathrm{KMO}=0.887$.

For Part $\mathrm{C}$ of the questionnaires Teachers and Parents - Inclusion of items in EC, justified the creation of two factors. However, several items converge in more than one factor, so it is preferable to subsequently perform the analysis items individually (Table 10).

After the factor analysis has become necessary to internal consistency analysis of the scales used.

\subsection{Analysis of the internal consistency of scales used}

The internal consistency analysis allows studying measurement scales of properties and issues that make up. The procedure calculates internal consistency measures of scale and also provides information on the relationships between individual items on a scale.

Cronbach's alpha measures the internal consistency or accuracy of responses to a set of correlated variables, namely, as a set of variables represent a certain factor. Once the data has a multidimensional structure, Cronbach's alpha will be low. If the inter-variable correlations are high, then there is evidence that the variables belong to the same factor.

It is noticed that an internal consistency coefficient of 0.80 or more is regarded as "good" in most applications of Social Sciences and an internal consistency coefficient between 0.70 and 0.80 is considered always acceptable. In some studies admit-internal consistency values of 0.60 to 0.70 , which according to the literature is "weak".

\begin{tabular}{|c|c|}
\hline Factors & Items \\
\hline Factor 1 - ER & $\begin{array}{l}\text { 9. It is important to find a tool that will allow for the intensification of and an easier } \\
\text { communication between the School and the Guardian. } \\
\text { 10. The adoption of an Electronic Booklet may contribute to an improved communication } \\
\text { between the school and the Guardian. } \\
\text { 11. An Electronic Booklet may constitute an important work tool for Class Directors, } \\
\text { Teachers, Parents and School Principals. } \\
\text { 12. An Electronic Booklet may constitute a communication resource between every } \\
\text { Teacher and Guardians. }\end{array}$ \\
\hline
\end{tabular}




\begin{tabular}{|c|c|}
\hline & $\begin{array}{l}\text { 13. An Electronic Booklet may be used by School Principals to contact Teachers. } \\
\text { 14. An Electronic Booklet may be used by School Principals to contact Guardians. } \\
\text { 15. An Electronic Booklet offers more advantages than the Traditional Booklet where the } \\
\text { communication between the multiple school community actors is concerned. }\end{array}$ \\
\hline $\begin{array}{l}\text { Factor } 2 \text { - Impact of the } \\
\text { school-family relationship in } \\
\text { the teaching-learning process }\end{array}$ & $\begin{array}{l}\text { 1. The relationship between the family and the school is fundamental for the teaching- } \\
\text { learning process. } \\
\text { 3. Whenever the parents are involved the development of the students is potentially } \\
\text { improved. } \\
\text { 4. The participation of parents in the school benefits the Teachers and contributes to a } \\
\text { more constructive work on their part. } \\
\text { 5. Parents assume more favourable attitudes towards Teachers when they cooperate } \\
\text { constructively with each other. }\end{array}$ \\
\hline Factor 3 - TR & $\begin{array}{l}\text { 7. The Traditional Student Booklet constitutes an important tool in family-school } \\
\text { communications. } \\
\text { 8. Teachers regularly use the Traditional Booklet in their communications with Guardians. }\end{array}$ \\
\hline $\begin{array}{l}\text { Factor } \mathbf{4} \text { - School-family } \\
\text { relationship difficulties }\end{array}$ & $\begin{array}{l}\text { 2. The relationship between the school and the family is not always easy and stands out as } \\
\text { a complex relationship. } \\
\text { ** 6. Parents can easily head to the school during the receiving hours appointed by Class } \\
\text { Directors and in meeting days. }\end{array}$ \\
\hline
\end{tabular}

Table 11: Organization of factors and items

For the first dimension, Factor 1 - CE, the Cronbach's alpha is higher than the value of 0.80 , so we can consider the appropriate data as one-dimensional (Table 12).

For Factor 2 - school-family relationship influence on teaching-learning process, the Cronbach's alpha is higher than the value of 0.70 , so we can consider acceptable as onedimensional data (Table 12).

For Factor 3 - CT, the Cronbach's alpha is close to the value of 0.70 , so we can consider acceptable as one-dimensional data (Table 12).

For Factor 4 - Difficulties in school-family relationship, the Cronbach's alpha is less than the value of 0.70 , so we cannot consider acceptable as one-dimensional data (Table 12).

The scale used for Part B - Student Handbook is suitable for measuring the factors constructed for this sample, except for the factor 4, it was still used with this limitation.

Factor 1

\begin{tabular}{|c|c|}
\hline Cronbach's Alpha & Nr. of Items \\
\hline 0.922 & 7 \\
\hline \multicolumn{2}{|c|}{ Factor 3} \\
\hline Cronbach's Alpha & Nr. of Items \\
\hline 0.661 & 4 \\
\hline
\end{tabular}

Factor 2

\begin{tabular}{cc}
\hline Cronbach's Alpha & Nr. of Items \\
\hline $\mathbf{0 . 7 3 0}$ & 4 \\
\hline \multicolumn{2}{c}{ Factor $\mathbf{4}$} \\
\hline Cronbach's Alpha & Nr. of Items \\
\hline $\mathbf{0 . 3 6 1}$ & 2 \\
\hline
\end{tabular}

Table 12: Cronbach's Alpha results for each factor

It was requested to Teachers and Parents to indicate advantages and disadvantages in the use of EB. The advantages suggested the use of the EB by teachers and parents were $84.7 \%$ and $84.3 \%$, respectively. Regarding the disadvantages, these were $24.3 \%$ and $20.2 \%$ Teacher/ Parent. The use of the advantages of the most mentioned EB for Teachers and Parents were: "faster, efficient and secure communication"; "Paper economy"; "Decreased repetitive work"; "Personalized access to information, anytime and anywhere"; "Daily monitoring" and "virtual presence". The answers to the question of the disadvantages in the use of EB, respondents were goals in his claims, arguing that there are no disadvantages, the possibility that not everyone has access to the internet and particularly the lack of computer literacy. 
The questionnaire focused on questioning part $\mathrm{C}$ of Parents and Teachers about the inclusion of items in EB. It appears that 95\% of parents and 94\% of teachers think that all items from the TB should be part of an EB (Chart 1).

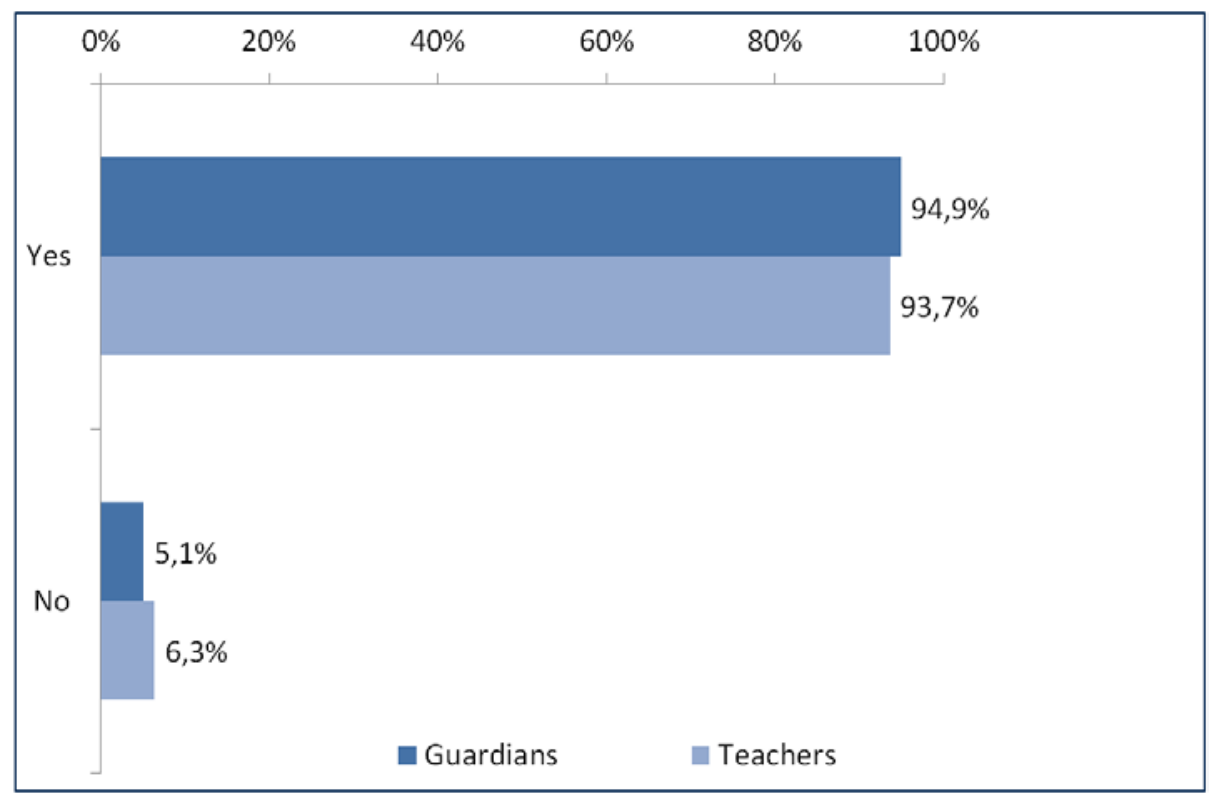

Chart 1: Frequency of Parents and Teachers to the question: "Should all items in the handbook Traditional student be part of a Handbook Electronics?"

Parents and Teachers were requested to indicate the degree of agreement with the inclusion of the following items in a possible EB presented in Table 13.

\begin{tabular}{|rl|}
\hline \multicolumn{1}{|c|}{ Items } \\
\hline 1. & Absence justifications by the Guardians. \\
\hline 2. & Absence management by the Class Director. \\
\hline 3. & Mid-term evaluation record. \\
\hline 4. & Evaluation criteria and tools for each subject. \\
\hline 5. & Student self-assessment forms. \\
\hline 6. & Communication management (Messages, SMS and Emails) \\
\hline 7. & Videoconference \\
\hline
\end{tabular}

Table 13: Inclusion of items in a possible EC

The answers to all of the items have a high average agreement, superior to the claims 3,1 and 2 followed by 4, 6, 5 e 7 .

The answers given by members Teachers in the sample of the study, the items have an average high agreement to the claims 2, 3, 4, 6 e 1 and after 5, below 7 .

It is requested, although the elements participating in the study who said they had some items that in their view should be included in EB. Given the variety of responses it was decided to include the most significant, namely the registration of absences, interim evaluations, registry entries and school dropouts and communication between parents.

\section{4 - Presentation and discussion of the results in relation to research questions}

The study started from a set of integrated issues, either in the questionnaire directed to parents, whether directed at the teachers who were subjected to analysis.

The first research question, "Communication between schools and families is essential in the teaching-learning process," is associated with the factor 2 - school-family relationship 
influence on teaching and learning process that includes the following statements: 1, 3, 4 and 5 (Table 11).

Most parents (96.7\%) believe that the relationship between school and family is central to the teaching-learning process. This is also the perception expressed by the majority of teachers (99.3\%) (Chart 2).

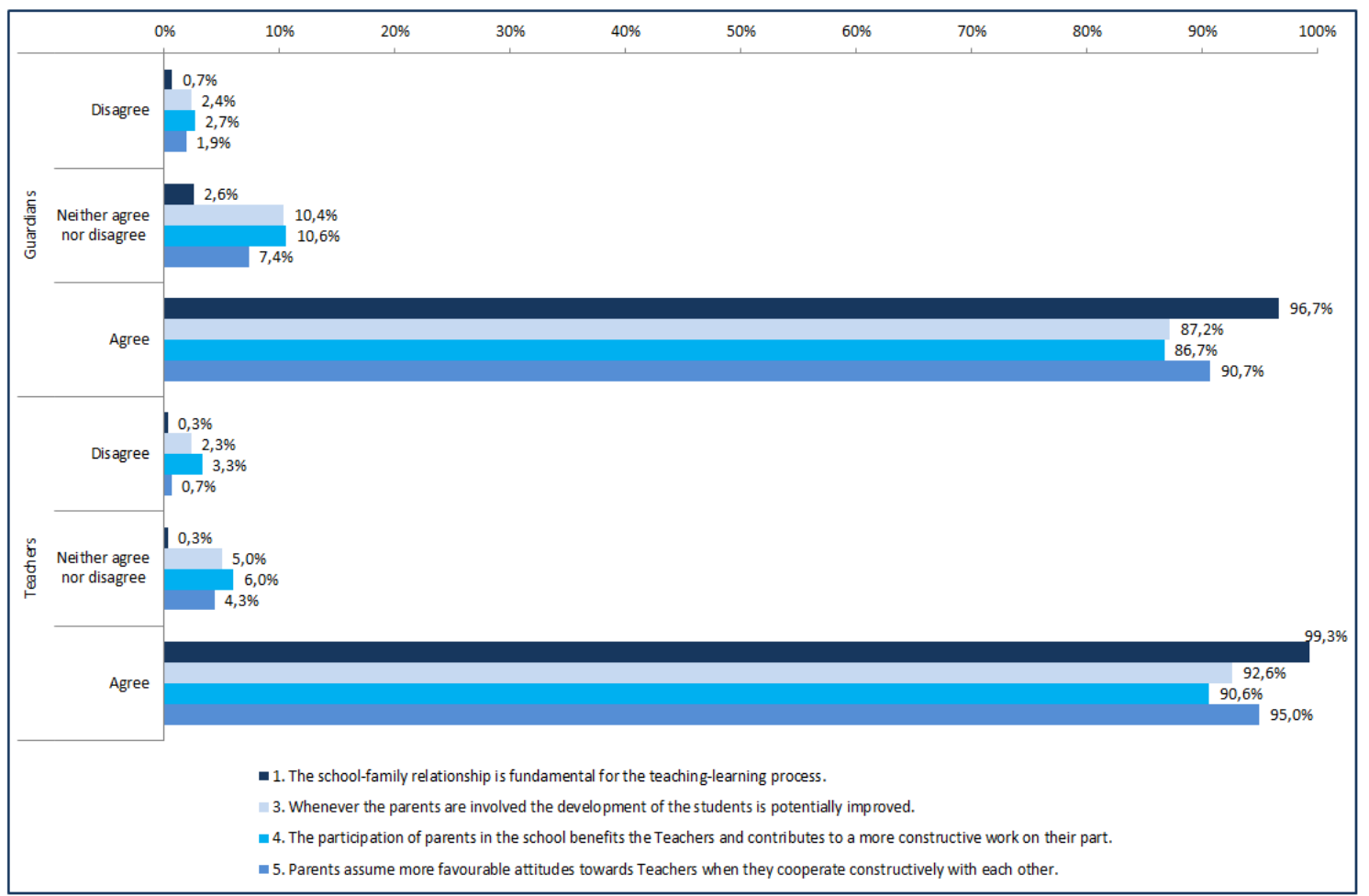

Chart 2: Relative Frequency of answers of Parents and Teachers

The observed average values have variations with all the items to submit a high agreement for either parents or Teachers. Factor 2 - school-family relationship influence on teachinglearning process thus presents an average of 4.49 for Parents and 4.55 for Teachers, quite close to the maximum possible value. In conclusion, we can state that both parents as Teachers, communication between the school and the family is fundamental in the teachinglearning process (Chart 3). 


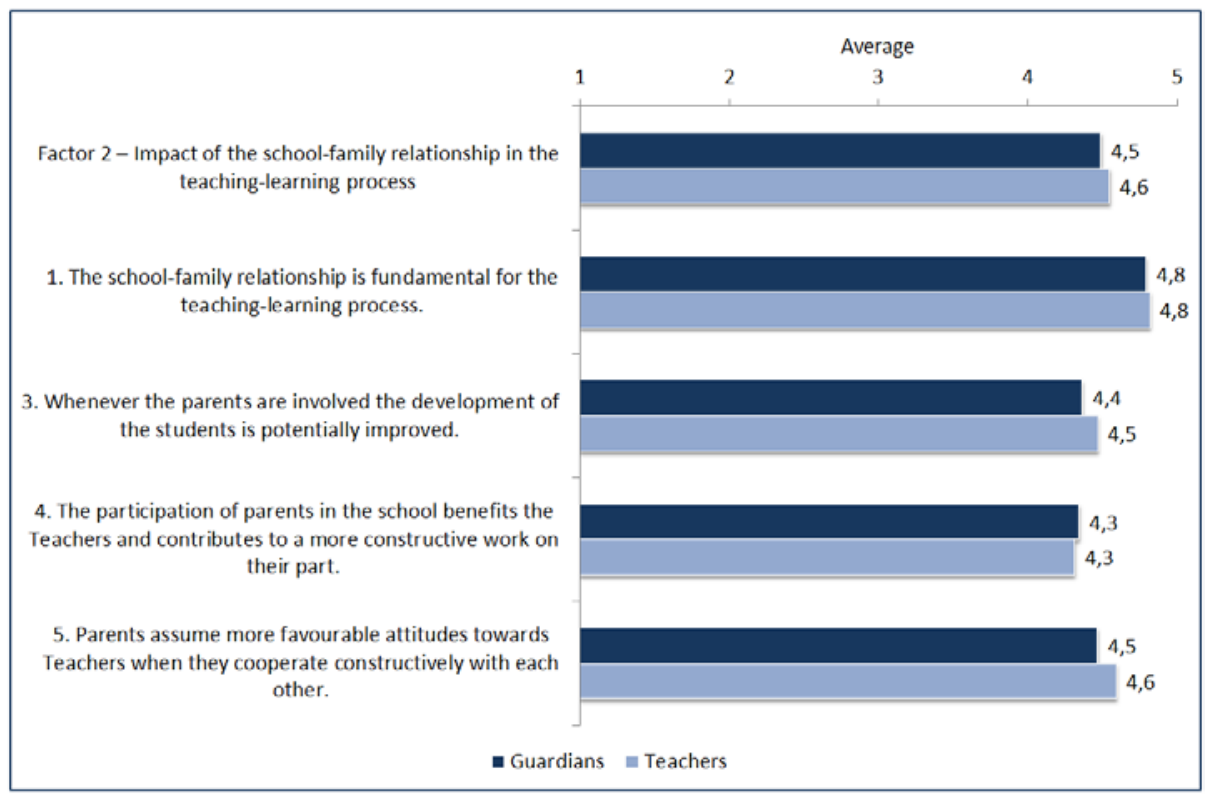

Chart 3: Mean values observed of Parents and Teachers

Analysis of the second research question "TB is a key tool in communicating school-family" is associated with Factor 3 - TB, which includes the statements: 7 and 8 (Table 11). Teachers uses very regularly to the student TB in communicating with parents. In fact, whether the parents (88.8\%) and Teachers (87.9\%) believe that the TB of the student is an important tool in communicating school-family (Chart 4).

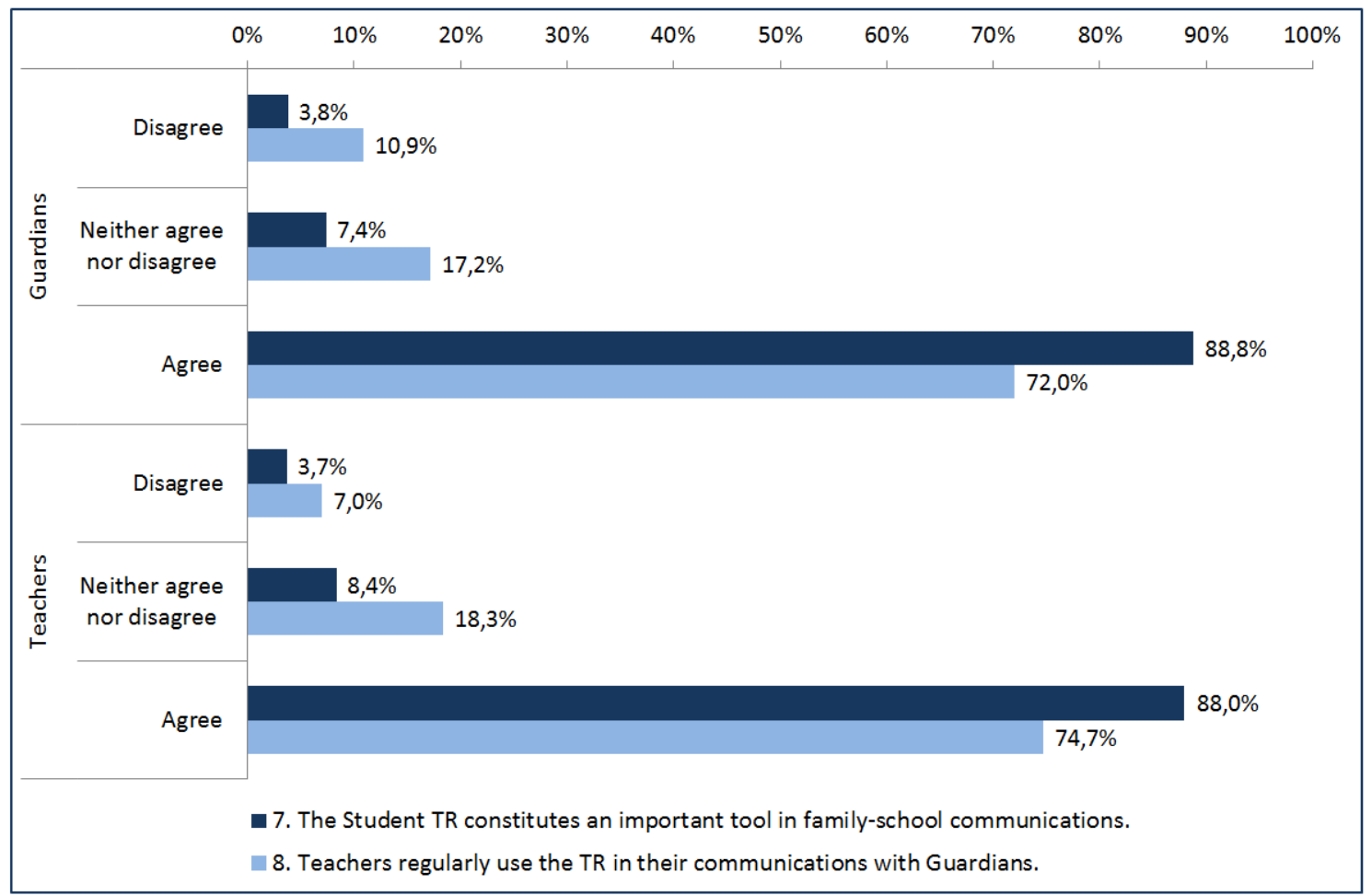

Chart 4: Relative frequency of answers of Parents and Teachers

The observed average values present the illustrated variations, with all the items to submit a high concordance for either parents or Teachers. Factor 3 - TB, and presents an average of 4.20 to 4.13 for Parents and Teachers, quite close to the maximum possible value.

In conclusion, we can state that both parents as Teacher, the TB is an essential tool in communicating school-family (Chart 5). 


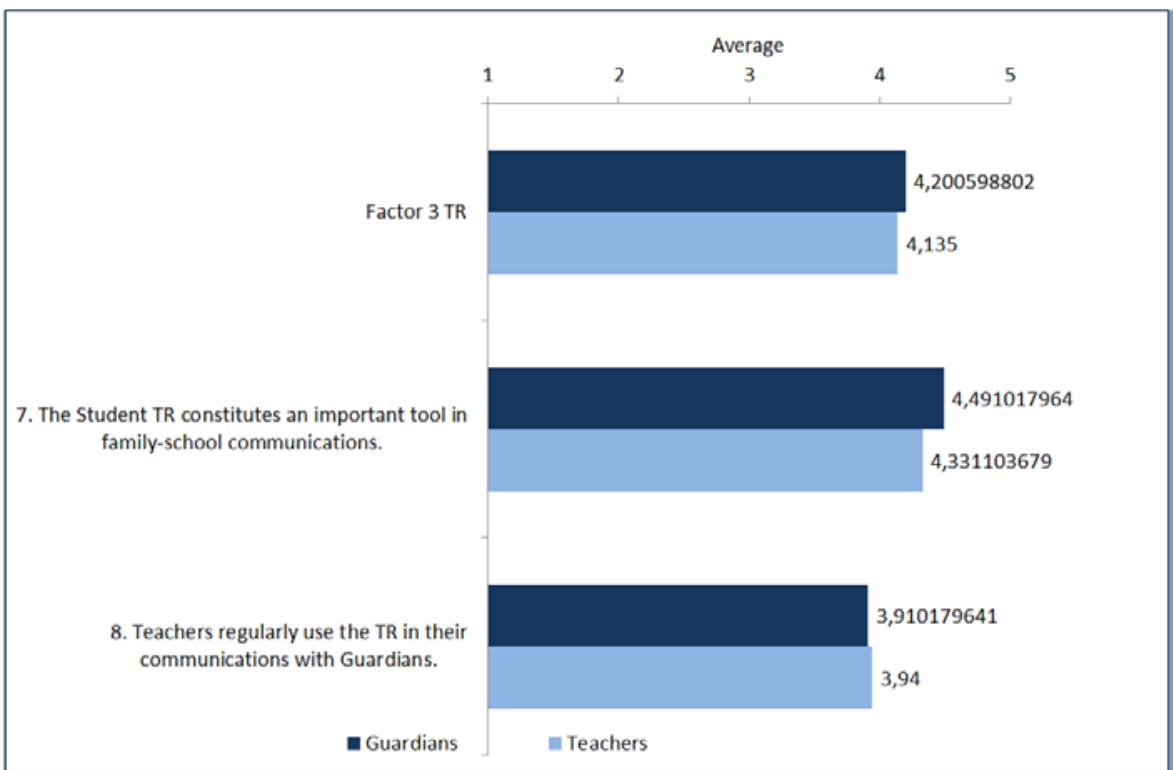

Chart 5: Average values observed of Parents and Teachers

The analysis of the research question "The EC enhances and improves school-family communication," is associated with the analysis of Factor 1 - EB, and integrates the statements: 9, 10, 11, 12, 13, 14 and 15 (Table 11).

Parents in the sample (83.9\%) and teachers (92.3\%) are unanimous as to the importance of finding a way to provide an intensification and greater ease in communication between the school and the Education Officer. Parents (78\%) and teachers (87.3\%) even admit that a EB can be a communication resource and labor, between school and family. Most parents (73\%) and teachers (82\%) believe that the EC may have more advantages compared to TB (Chart 6).

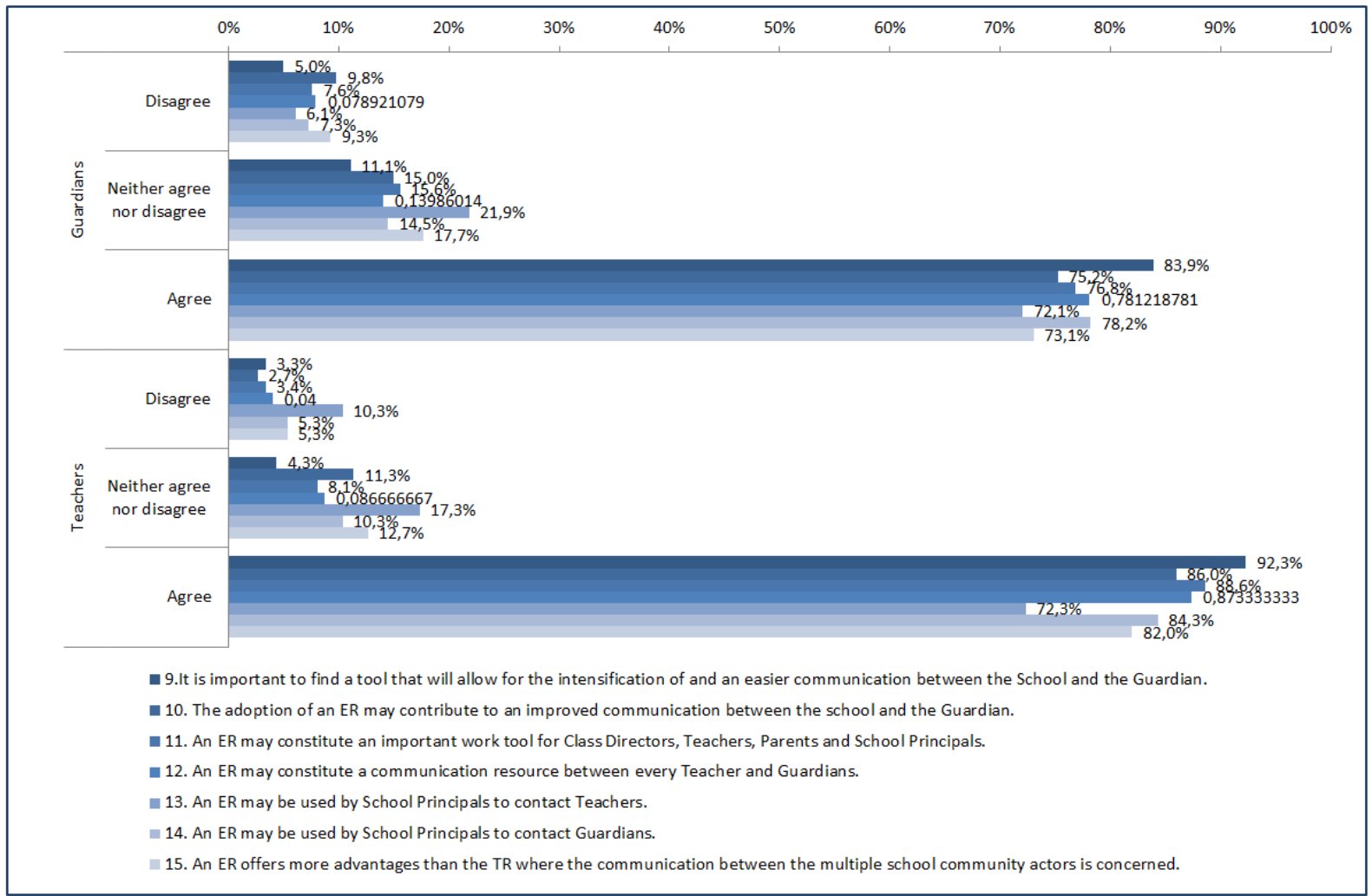

Chart 6: Relative frequency of answers of Parents and Teachers 
The observed average values present the illustrated variations, with all the items to submit a high concordance for either parents or Teachers. Factor 1 - EB and has an average value of 4.11 to 4.33 for Parents and Teachers, quite close to the maximum possible value. In conclusion, we can state that both parents as Teacher, the EB enhances and improves communication between the school and the family (Chart 7).

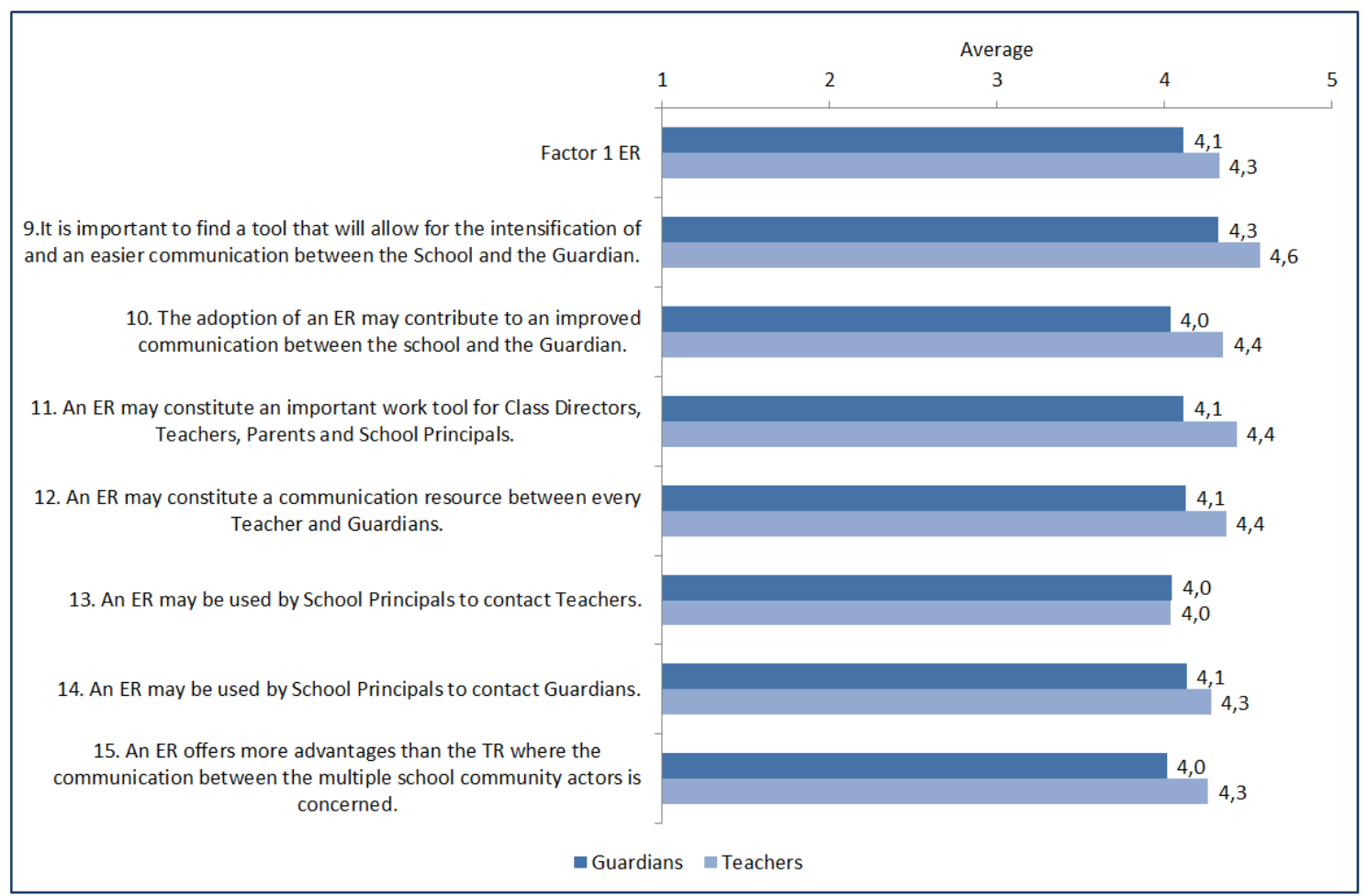

Chart 7: Average values observed of Parents and Teachers

The same is reflected with scattering measurements presented, showing relatively low values for the standard deviation with values less than one, or the coefficient of variation less than or equal to twenty percentages (Tables 14, 15 and 16). So, it seems, a good dispersion of the results, pointing to a greater homogenization of answers and consequently making the most representative average of reality.

\begin{tabular}{|c|c|c|c|c|c|c|c|c|}
\hline & \multicolumn{4}{|c|}{ Guardians } & \multicolumn{4}{|c|}{ Teachers } \\
\hline & $N$ & $\begin{array}{l}\text { Averag } \\
\quad \mathrm{e}\end{array}$ & $\begin{array}{l}\text { Standar } \\
d \\
\text { Deviati } \\
\text { on } \\
\end{array}$ & $\begin{array}{l}\text { Coefficient } \\
\text { of Variation }\end{array}$ & $\mathrm{N}$ & Average & \begin{tabular}{|c} 
Standar \\
$\mathrm{d}$ \\
Deviatio \\
$\mathrm{n}$
\end{tabular} & $\begin{array}{l}\text { Coefficient } \\
\text { of Variation }\end{array}$ \\
\hline $\begin{array}{l}\text { Factor } 2-\text { Influence of the school-family } \\
\text { relationship in the teaching-learning process. }\end{array}$ & 1002 & 4,49 & 0,54 & $12 \%$ & 300 & 4,55 & 0,47 & $10 \%$ \\
\hline $\begin{array}{l}\text { 1. The relationship between the school and the } \\
\text { family is fundamental for the teaching-learning } \\
\text { process. }\end{array}$ & 1002 & 4,79 & 0,53 & $11 \%$ & 300 & 4,82 & 0,44 & $9 \%$ \\
\hline $\begin{array}{l}\text { 3. Whenever the parents are involved, the } \\
\text { development conditions of the students are } \\
\text { potentially improved. }\end{array}$ & 1001 & 4,37 & 0,79 & $18 \%$ & 299 & 4,47 & 0,74 & $17 \%$ \\
\hline $\begin{array}{l}\text { 4. The participation of the parents in the school } \\
\text { benefits the Teachers, and contributes to a more } \\
\text { constructive work on their part. }\end{array}$ & 1001 & 4,34 & 0,79 & $18 \%$ & 299 & 4,31 & 0,77 & $18 \%$ \\
\hline $\begin{array}{l}\text { 5. Parents assume more favourable attitudes } \\
\text { towards Teachers when they cooperate } \\
\text { constructively with each other. }\end{array}$ & 1001 & 4,47 & 0,74 & $16 \%$ & 299 & 4,60 & 0,61 & $13 \%$ \\
\hline
\end{tabular}

Table 14: Factor 2 dispersion measures - Influence of the School / Family in the teaching-learning process and its items. 


\begin{tabular}{|c|c|c|c|c|c|c|c|c|}
\hline & \multicolumn{4}{|c|}{ Guardian } & \multicolumn{4}{|c|}{ Teacher } \\
\hline & $\mathrm{N}$ & $\begin{array}{c}\text { Averag } \\
\mathrm{e}\end{array}$ & $\begin{array}{l}\text { Standar } \\
\text { d } \\
\text { Deviati } \\
\text { on }\end{array}$ & $\begin{array}{l}\text { Coefficient } \\
\text { of Variation }\end{array}$ & $\mathrm{N}$ & Average & $\begin{array}{l}\text { Standar } \\
\mathrm{d} \\
\text { Deviatio } \\
\mathrm{n}\end{array}$ & $\begin{array}{l}\text { Coefficient } \\
\text { of Variation }\end{array}$ \\
\hline Factor 3 - Traditional Booklet & 1002 & 4,20 & 0,83 & $20 \%$ & 300 & 4,13 & 0,73 & $18 \%$ \\
\hline $\begin{array}{l}\text { 7. The Traditional Student Booklet } \\
\text { constitutes an important tool in family- } \\
\text { school communications. }\end{array}$ & 1002 & 4,49 & 0,82 & $18 \%$ & 299 & 4,33 & 0,79 & $18 \%$ \\
\hline $\begin{array}{c}\text { 8. Teachers regularly use the Traditional } \\
\text { Booklet in their communications with } \\
\text { Guardians. }\end{array}$ & 1002 & 3,91 & 1,08 & $28 \%$ & 300 & 3,94 & 0,91 & $23 \%$ \\
\hline
\end{tabular}

Table 15: Measures of dispersion of Factor 3 - TB.

\begin{tabular}{|c|c|c|c|c|c|c|c|c|}
\hline & \multicolumn{4}{|c|}{ Guardian } & \multicolumn{4}{|c|}{ Teacher } \\
\hline & $\mathrm{N}$ & $\begin{array}{l}\text { Averag } \\
\text { e }\end{array}$ & $\begin{array}{l}\text { Standar } \\
\text { d } \\
\text { Deviati } \\
\text { on }\end{array}$ & $\begin{array}{l}\text { Coefficient } \\
\text { of Variation }\end{array}$ & $\mathrm{N}$ & $\begin{array}{c}\text { Averag } \\
\text { e }\end{array}$ & $\begin{array}{l}\text { Standar } \\
\text { d } \\
\text { Deviati } \\
\text { on }\end{array}$ & $\begin{array}{l}\text { Coefficient } \\
\text { of Variation }\end{array}$ \\
\hline Factor 1 - Electronic Booklet & 1002 & 4,11 & 0,85 & $21 \%$ & 300 & 4,33 & 0,71 & $16 \%$ \\
\hline $\begin{array}{l}\text { 9. It is important to find a tool that will allow for the } \\
\text { intensification of and an easier communication between } \\
\text { the school and the Guardian. }\end{array}$ & 1002 & 4,32 & 0,91 & $21 \%$ & 299 & 4,57 & 0,73 & $16 \%$ \\
\hline $\begin{array}{l}\text { 10. The adoption of an Electronic Booklet may } \\
\text { contribute to an improved communication between the } \\
\text { school and the Guardian. }\end{array}$ & 1002 & 4,03 & 1,09 & $27 \%$ & 300 & 4,35 & 0,81 & $19 \%$ \\
\hline $\begin{array}{l}\text { 11. An Electronic Booklet may constitute an important } \\
\text { work tool for Class Directors, Teachers, Parents and } \\
\text { School Principals. }\end{array}$ & 1002 & 4,12 & 1,02 & $25 \%$ & 298 & 4,43 & 0,81 & $18 \%$ \\
\hline $\begin{array}{l}\text { 12. An Electronic Booklet may constitute a } \\
\text { communication resource between every Teacher and } \\
\text { Guardians. }\end{array}$ & 1001 & 4,13 & 1,01 & $24 \%$ & 300 & 4,37 & 0,82 & $19 \%$ \\
\hline $\begin{array}{l}\text { 13. An Electronic Booklet may be used by School } \\
\text { Principals to contact Teachers. }\end{array}$ & 1002 & 4,05 & 1,01 & $25 \%$ & 300 & 4,04 & 1,14 & $28 \%$ \\
\hline $\begin{array}{l}\text { 14. An Electronic Booklet may be used by School } \\
\text { Principals to contact Guardians. }\end{array}$ & 1002 & 4,13 & 1,00 & $24 \%$ & 300 & 4,28 & 0,90 & $21 \%$ \\
\hline
\end{tabular}

Table 16: Measures of dispersion of Factor 1 - EB.

\section{Conclusion}

The collaboration between school and family, two key institutions in the child's education is critical to improving the teaching-learning process, contributing to such targeted educational success. Education is a task that must be shared by teachers, parents and community institutions (Paro, 2003).

We understand that in every communication teaching-learning process and particularly the means to communicate are essential to a successful educational, we direct a study to understand the opinion of Parents and Teachers on the feasibility of adopting EC in relation to school and family.

As a starting point for the study development it was put up three assumptions: A1: The educational community values communication between school and family; A2: The TB is a key instrument in school-family communication; A3: The EB enhances communication between the school and the family.

It was found, for the answers given, that the prospects of Teachers and Parents communication between schools and families is critical in the process of teaching and learning as the factor concerning the influence of school-family relationship in the teachinglearning process has a value Average 4.49 4.55 Parent and Teacher, quite close to the maximum possible value.

For Teachers and Parents TB is a key instrument in school-family communication. At this time, for many parents the only way to communicate with teachers is through the TB, since they cannot travel to the school opening hours. 
From the point of view of Parents and Teachers, participants in the study, the EB can enhance and improve communication between the school and the family. Indeed, the analysis made to the answers given by participant elements in the study concluded that the Factor 1 - EB, has an average value of 4.11 to 4.33 for Parents and Teachers, quite close to the maximum possible value.

Most Teachers and Parents' claim that the EB should include the items already listed in TB. They also point out the importance of including the following: registration of absences, interim evaluations, registry entries and exits from school and communication between parents.

Given the results achieved it was found that the three assumptions were strengthened, because for the majority of respondents (Parents and Teachers), communication between school and family is essential in the teaching-learning process; TB appears also as a key tool in the school-family communication and EB power and improves school-family communication.

Thus, the EB could take in an innovative, dynamic and assertive, a facilitator of communication role between school and family, making it possible to establish partnerships and improve the teaching-learning process.

In this sense, justified the development of a web application - the "EB" - which aims to consult all the information associated with the student, as well as enable an easier, fast and secure communication between the school and the family.

\section{References}

Abrantes, B. (2009). Concepção e desenvolvimento de um ambiente de aprendizagem pessoal baseado em ferramentas web 2.0: estudo de caso da plataforma Sapo Campus. Universidade de Aveiro.

Abreu, A., Rocha, Á. \& Cota, M.P. (2015). Perceptions of Teachers and Guardians on the Electronic Record in the School-Family Communication. In Open and Big Data Management and Innovation, 48-62. Springer International Publishing. doi: 10.1007/9783-319-25013-7_5.

Alho, S., \& Nunes, C. (2009). Contributos do director de turma para a relação escola-família. Revista Educação/PUCRS, 32(2), 150-158. Porto Alegre.

Anastasi, A. (1990). Psychological testing. 6th ed. New York. MacMillan.

Anastasi, A. (1985). Psychological testing: Basic concepts and common misconceptions. In A. M. Rogers \& C. J. Scheirer (Eds.), The G. Stanley Hall Lecture Series, 5, 87-120. Washington, DC: American Psychological Association.

Angelo, C. F. (1991). A estrutura do Mercado de transportes, a conduta e o desempenho das empresas ferroviárias brasileiras. tese de livre-docência em Administração - Faculdade de Economia, Administração e Contabilidade, Universidade de São Paulo.

Bartlett, M. S. (1951). The effect of standardization on a chi square approximation in fator analysis. Biometrika, 337-344. doi: 10.2307/2332580.

Batista, I. (2005). Dar rosto ao futuro: A educação como compromisso ético. Porto: Profedições.

Beaudichon, J. (2001). A comunicação - Processos, Formas, e Aplicações. Porto: Porto Editora.

Bell, J. (2002). Como realizar um projeto de investigação: Um guia para a pesquisa em Ciências Sociais e da Educação. Lisboa: Gradiva. 
Berto, R. M. V. S.; Nakano, D. N. (2000). A produção científica nos Anais do Encontro Nacional de Engenharia de Produção: um levantamento de métodos e tipos de pesquisa. Produção, v. 9, n. 2, p. 65-76, 2000. doi: 10.1590/S0103-65131999000200005

Berto, R. M. V. S., \& Nakano, D. N. (2014). Revisitando a produção científica nos anais do Encontro Nacional de Engenharia de Produção. Production Journal, 24(1), 225-232. Doi: doi: 10.1590/S0103-65132013005000007

Bhering, E., \& Siraj-Blatchford, I. (1999). A relação escola-pais: um modelo de trocas e colaboração. Cadernos de pesquisa, 106, 191-216.

Boonen, A. (2000). Pourquoi utiliser les technologies de l'information et de la communicationdans le domaine de l'éducation? In J. J. Scheffknecht (Ed.), Les technologies de l'informationà l'école: raisons et stratégies pour un investissement. Strasbourg: Conseil de l'Europe.

Canhota, C. (2008). Qual a importância do estudo piloto? In: Silva, E. E.(Org.). Investigação passo a passo: perguntas e respostas para investigação clínica. Lisboa: APMCG, 69-72.

Carvalho, M. E. P. D. (2000). The relationship between the family and the school and its gender implications. Cadernos de Pesquisa, (110), 143-155. doi: 10.1590/S010015742000000200006.

Castells, M. (1999). A Sociedade em rede. São Paulo: Paz e Terra.

Castells, M. (2001). O poder da identidade-a era da informação: economia, sociedade e cultura, (2). São Paulo: Paz e Terra.

Castells, M. (2002). The Internet Galaxy - Reflections on the Internet, Business, and Society. Oxford University Press.

Castells, M. (2003). O fim do milénio. Lisboa: Fundação Calouste Gulbenkian.

Costello, A., \& Osborne, J. (2005). Best Practices in Exploratory Fator Analysis: Four Recommendations for Getting the Most from your Analysis. Pratical Assessment, Research \& Evaluation, 1-9.

Creswell, J. (2003). Research design: Qualitative, quantitative and mixed methods approach (2nded.).Thousand Oaks, CA: SAGE Publications.

Despacho No 38/SERE/88, D. d. R. d. d. s. (1988).

Dusi, P. (2012). The Family-School Relationships in Europe: A Research Review, CEPS Journal, 2(1), pp. 13-33.

Epstein, J. L. (2010). School/family/community Partnerships: Caring for the Children We Share: When Schools Form Partnerships with Families and the Community, the Children Benefit. These Guidelines for Building Partnerships Can Make It Happen. Phi Delta Kappan, 92(3), 81.

Epstein, J. L. (2001). School, family, and community partnerships: Preparing educators and improving schools. Westview Press, 5500 Central Avenue, Boulder, CO 80301.

Fortin, M. F., Côte, J., \& Filion, F. (2009). Fundamentos e etapas do processo de investigação. Loures: Lusodidacta.

Gepe. (2010). Comunidades Educativas em Rede. Estudo Estratégico. Lisboa, 1.

Ghiglione, R., \& Matalon, B. (2001). O Inquérito - Teoria e Prática. Oeiras: Celta Editora.

Gil, A. C. (1999). Métodos e Técnicas de Pesquisa Social. São Paulo: Atlas. 
Gil, A. C. (2010). Como elaborar projetos de pesquisa. São Paulo: Atlas.

Grant, L. (2009). Children's role in home-school relationships and the role of digital technologies. Reino Unido:Future Lab.

Groves, R. M., Fowler Jr, F. J., Couper, M. P., Lepkowski, J. M., Singer, E., \& Tourangeau, R. (2011). Survey methodology, ( 561). John Wiley \& Sons.

Guimarães, R. C., \& Sarsfield Cabral, J. A. (2010). Estatística, $2^{a}$ Edição. Verlag Dashöfer.

Henderson, A. T., \& Berla, N. (1994). A new generation of evidence: The family is critical to student achievement.

Hill, M., \& Hill, A. (2005). Investigação por Questionário. Lisboa: Edições Sílabo.

Hill, M., \& Hill, A. (2002). Investigação por questionário (2a ed.). Lisboa: Sílabo.

Kaiser, H. F. (1974). An index of fatorial simplicity. Psychometrika, 31-36.

Kryger, N., \& Ravn, B. (2009). Homework in Denmark: What kind of links between family and school. International Perspectives on Student Outcomes and Homework. FamilySchool-Community Partnerships, 7-24.

Lawson, M.A. (2003) School-Family Relations in Context Parent and Teacher Perceptions of Parent Involvement. Communities in Schools of Sacramento, Inc. Urban Education, 38(1), 77-133. Doi: 10.1177/0042085902238687.

Leong, F. T. L., \& Austin, J. T. (2006). The Psychology Research Handbook. Second Edition. Sage Publications, Thousand Oaks, California, 516.

Lévy, P. (2003). Cibercultura. São Paulo,34.

Lima, L., \& Sá, V. (2002). A participação dos Pais na governação democrática das escolas. In: Lima, J. (Org.). Pais e professores, um desafio à cooperação. Porto: Edições Asa.

Lourenço, L. P. R. (2008). Envolvimento dos Encarregados de Educação na Escola: Conceções e Práticas. Universidade de Lisboa.

Mackey, A.; Gass, S. (2005). Common data collection measures. In:_.Second language research: methodology and design. Mahwah: Lawrence Erlbaum, 43-99.

Marôco, J. (2011). Análise estatística com o SPSS Statistics. ReportNumber, Lda.

Marques, R. (1992). Colaboração Escola-Famílias: um conceito para melhorar a Educação. Ler Educação, 8.

Marques, R. (1998). Os desafios da sociedade de informação. In R. Marques, M.

Mattelart, A. (2003). The Information Society. London: Sage Publications.

McLean, N. (2009). Technology can bridge the gap between parents and schools. The Independent.

Mitchell, C. (2008) Parent Involvement in Public Education: A Literature Review.

Montadon, C., \& Perrenoud, P. (2001). Entre Pais e Professores, um diálogo impossível? Para uma análise sociológica das interações entre a família e a escola. Oeiras: Celta.

Pardal, L., \& Correia, E. (1995). Método e técnica de investigação social. Porto: Areal Editores.

Paro, V. (2003). Qualidade do Ensino: A Contribuição dos Pais. São Paulo: Xamã. 
Pedro, N., \& Matos, J. F. (2010). Comunidades Educativas em Rede: Estudo Estratégico (Vol. I e II).

Pereira, A. (2006). Análise de dados para Ciências Sociais e Psicologia. Lisboa: Edições Sílabo.

Pereira, C. B. (2004). O marketing do lugarzinho: uma aplicação exploratória da técnica de índice de preços hedônicos a jovens consumidores de restaurantes na cidade de São Paulo. Tese de Doutoramento em Administração - Faculdade de Economia, Administração e Contabilidade, Universidade de São Paulo. São Paulo, 165.

Quivy, R., \& Campenhoudt, L. V. (2005). Manual de Investigação em Ciências Sociais, 4. ${ }^{\text {a }}$ Edição. Lisboa: Gradiva.

Salvador, P., \& Rocha, Á. (2014). An assessment of content quality in websites of basic and secondary Portuguese schools. In New Perspectives in Information Systems and Technologies, (1), 71-82. Springer International Publishing. Doi: 10.1007/978-3-31905951-8_8.

Sarmento, T. (2005). (RE) pensar a interação escola família. Revista Portuguesa de Educação, $18,53-75$.

Sarmento, T., \& Marques, J. (2002). A Escola e os Pais, Coleção Infans. Braga: Centro de Estudos da Criança.

Skilbeck, M. (1998). Os sistemas educativos face à sociedade da informação. In R. Marques, M. Skilbeck, J. M. Alves, H. Steedman, M. Rangel \& F. Pedró (Eds.), Na sociedade da informação - O que aprender na escola?. (pp. 11-32). Colecção Perspectivas Actuais. Rio Tinto: Edições Asa.

Silva, A. J. A., Pérez Cota, M., \& Rocha, A. (2013). Electronic Handbook: Collaboration school-family in digital environments. In Information Systems and Technologies (CISTI), 2013 8th Iberian Conference on (pp. 1-6). IEEE.

Silva, P. (2002). Escola-família: Tensões e potencialidades de uma relação. in Jorge Ávila de Lima (Org.), Pais e Professores, Um Desafio à Cooperação. Porto, Edições ASA.

Stevens, J. (1996). Applied multivariate statistics for the social sciences (3rd edn). Mahway, NJ: Lawrence Erlbaum.

Tabachnik, B. G., \& Fidell, L. S. (2006). Using Multivariate Statistics. (5.th Ed.). Pearson Education.

Tuckman, B. W. (2005). Manual de investigação em Educação, 3. ${ }^{a}$ Edição. Lisboa: Fundação Calouste Gulbenkian.

Villas-Boas, M. (2000). A parceria entre a escola, a família e a comunidade: reuniões de Pais. Lisboa: Edição do Departamento de Avaliação Prospetiva e Planeamento do Ministério da Educação.

Villas-Boas, M. (2001). Escola e família: uma relação produtiva de aprendizagem em sociedades multiculturais. Lisboa: Escola Superior João de Deus. 